\title{
Research on the Legal Risk and Governance for the Affiliated Business in the Construction Industry
}

\author{
Yang Yang \\ Southwest University, Chongqing, China \\ Email: yangyangtangxin@vip.qq.com
}

Received 19 March 2015; accepted 25 April 2015; published 4 May 2015

Copyright (C) 2015 by author and Scientific Research Publishing Inc.

This work is licensed under the Creative Commons Attribution International License (CC BY).

http://creativecommons.org/licenses/by/4.0/

(c) (i) Open Access

\begin{abstract}
Construction industry is undoubtedly one of the fastest-growing industries in China. But, due to its inadequate technique, the operation of this industry is not standardized. Its affiliated business causes confusion. The operation of the whole industry is at a series of civil, administrative, and criminal legal risks, because the affiliated party usually does not have the corresponding qualifications. All risks need to be resolved and prevented in three aspects. Firstly, the legal system for the qualification management should be improved and the internal management of the enterprise should be promoted. Secondly, unreasonable prohibitions should be changed. And thirdly, the insurance system of the industry should be perfected.
\end{abstract}

\section{Keywords}

\section{Construction Industry, Affiliated Business, Legal Risk and Governance}

\section{Introduction}

With development of reform and opening up, the construction industry has unquestionably become the pillar industry in China at present. However, because the technical specifications in the construction industry is relatively low, many problems happened behind the rapid development of this industry, for example, the technology lags behind, low production efficiency is low, the legal system is not perfect and the industry is not regulated to run. Especially for the affiliated business’ operation ways, it will bring a series of legal risks in nature. Measures must be taken to deal with it in order to solve these problems. It is usually associated with the illegal subcontract for the affiliated business in the construction industry. A series of legal risk will be emerged in the process, such as the civil dispute, the administrative dispute, the criminal dispute and so on. 
The first is the civil legal risk. First of all, the construction side can know beforehand that the parties awarding the contract have the construction projects through personnel relations. In order to successfully contract the project, they are always affiliated to the contractors who own the relevant qualification level, and then the contractor will bid the projects to achieve their goals for contracting the projects. The two parties sign the affiliated agreement in this period, which agrees that the construction side will pay the administration expenses and share all responsibilities that include the actual administrative responsibilities of the projects in construction practice. But the contractors always ignore their administration and the construction side is always lacking of self-discipline. These problems would lead the legal dispute. Secondly, the construction side generally has some previous dealings with the party awarding the contract in the practice. The contractor is lacking of their effective supervision for the construction projects. The situation that the bill is unable to verify will happen and the creditor and debt dispute is incurred when the parties awarding the contract directly pay the construction side for the project payment without the contractor's approval. Thirdly, the construction side signed the contract of the materials supply and so on in the name of the contractor in the practice of construction, but they were diverted to be used from this construction project to other project when the materials were used. It would happen that the materials cost that was used the affiliated project is less than its total cost. And it will cause that the party awarding the contract take legal action against the contractor or the contractor have a libel action against the construction side. Fourthly, according to the provisions of the legal interpretation on hearing the dispute case for the construction contract by the Supreme People's Court 最高人民法院关于审理建设工程施工合同纠纷案件适用法律问题 的解释, the conduct that the construction contract has been signed was invalid and the illegal incomes that the parties have already obtained were forfeited. That is to say, the two parties should not only share the risk that the affiliated agreement is invalid, but also should bear all losses caused by the forfeit of management gains. Fifthly, the warrandice could happen for the construction side's own self-interest. The constructor will bear the legal ability if the construction side promises to guarantee for public in the name of the constructor's branches and the debtor loss of liquidity.

The second is the administrative legal risk. According to the relevant provisions of the Building Ordinance 建筑法, it is regulated that they will accept various degree of administrative penalty if the party awarding the contract gives the construction project to the contractor who has not the relevant qualification and the project that the contractor unit have contracted are subcontracted or illegal subcontracted, such as to be ordered to make their corrections, to be fined, to be ordered to suspend their business for rectification, to forfeit their illegal incomes, to lower their qualification level, to revoke their licenses and so on (Gan Xianshuang \& Zhao Peng, 2013). Additionally, it would bring the risk of second time punishment for the civil dispute in the construction industry. According to the $21^{\text {st }}$ article of the Enterprise Qualification Regulation in the Construction Industry 建筑业企业资质管理规定, it is regulated that their qualification shall not be upgraded if the enterprises are maliciously in arrears with the subcontracting enterprises' project payment and the farmer's salary. The punishment degree to restrict the enterprise qualification's promotion, to lower their qualification level and to revoke their license is far greater than the civil effectiveness.

The third is the criminal legal risk. The phenomenon of the affiliated business is very common; its reasons is that the two parties are in a win-win situation. Theoretically speaking, the affiliated relation can still maintain as long as it does not cause the third party losses. And in practice, they can obtain the subsidy as the actual construction side after the affiliated party pays the administrative costs. Additionally, all factors will also increase the legal risk. For example, the comprehensive ability of the affiliated party is relatively poor, such as their performance, their personnel quality, the quality of management, their funds level, their equipment and other ways. It is difficult to be safe for the execution control in site and the safety measures are absent, and the contractor does not pay more attention to the construction project. The criminal responsibility of related subject was regulated for 12 provisions in the Building Ordinance. It can enough show that it can share the huge risk if the affiliated construction project is absent to supervise. And it is also an important factor to induce the criminal risk that the affiliated business management is loose, for example, the affiliated side makes unauthorized use of the contractor's name to sign the supply contract, the tenancy agreements and other contracts with the third side, and they will sell them to cash and disappear with all their money when they receive materials and equipment. Although the affiliated agreement was signed in advance by the two parties, it is easy to lead that the funds management is separated from the on-site supervision as their independent operation and responsibility for their own profits and losses. All will provide an opportunity for crime (Zhonghua Renmin Gongheguo Jianzhufa, 2005). 


\section{The Origin and Characteristics of the Affiliated Business}

It is associated with the planned economic system for the phenomenon of affiliated business, after all, which provides an economical means to break the state-owned, collective monopoly on resources. The affiliated business is so-called that the enterprise is in the name of other enterprises to run. For the construction industry, it refers to an action that a construction enterprise can allow other enterprises will undertake the engineering in the name of his enterprise in a certain period. It is essentially an action to contract and lease management for the affiliated business behavior. The corresponding provisions to the bidding and contracting of the construction project were made in the third chapter of the Building Ordinance. In practice, the affiliated business in the field of the construction industry refers to that the actual construction side who do not have the qualification or has the low qualification to contract the projects in the name of other construction enterprises who have the qualifications or have the higher qualifications, and is a behavior that they agreed to sign the affiliated business costs through the affiliation agreement. The affiliated two parties will become the subject of joint action in the civil action.

For the affiliated business in the field of construction industry, the affiliated side usually do not have qualification to contract the projects, or they have the qualification to contract the relevant projects but do not meet the qualification level that required by the party awarding the contract. And the contractor have the corresponding qualification to contract the projects, but they are lack of the ability and means to contract the projects, which the affiliated side have the corresponding ability. The two affiliated sides usually agreed on the administration costs caused in the name of their enterprise qualification, namely the affiliated fee in the affiliated agreement. The affiliated side is not only the actual builder for the construction, but also is the actual administrator, and the contractor does not undertake the specific engineering management in the process. Therefore, it is the common administrative mode in the affiliated business for it. It is the basic form even if the governing body is established or the company's executives are accredited. During the period of the affiliated business, the two parties show an organic whole for public, but they are still an individual for themselves, who are embodied in the characteristics of independent operation with responsibility for their own profits and losses, independent accountability. The affiliated contractor often appears in the name of their affiliated branch etc. It is broadly divided into two categories for the affiliated business' form. The first is to purely borrow its qualification. The two parties in such affiliated business can meet the qualification specification and construction abilities which are required for the construction, but the contractor's qualification level is relatively lower than the other party. The constructor enters a bid in the name of the head office in order to meet the requirements of the party awarding the contract. Their goal is to increase their chances to win the construction. The second is to contract in-house. These that adopt the affiliated ways are mainly individuals and organizations that do not have the qualification specification. In order to successfully contracting the project, the affiliated contractor will find the head office who meet the qualification requirement of the project in the construction market, and the head office employ the affiliated party as their employees who entrusted with the Officer in charge of construction, such as the Project Manger and so on (Huang Ping, 2009). In addition, the in-house contract are signed by them, and it is regulated in the contract that the affiliated contractor will share all risks and costs of the project and that the other party will collect the administration expenses to be responsible for some affairs for public.

\section{The Way of Thinking to Govern the Affiliated Business}

Improving the legal system of the qualification management and promoting the enterprise management. Firstly, there are many affiliated enterprises that have the construction qualification in the construction enterprises in the current, but they are still unable to directly contract with the projects and can only choose the affiliated business. This is because the phenomena that the tenderee ask too much of the bidder's qualification generally exist on the market. Namely, the project that can be completed by the second level enterprise is required to be finished by the enterprise that have the premium quality, and the project that can be completed by the professional qualification enterprise is required to be finished by the enterprise who have the general contracting qualification (Lu Gang \& Yan Le, 2012). And because the high qualified enterprises is more superior than the low qualified enterprises to contract the projects, the low qualified enterprises can only obtain it by the ways to subcontract it from the high qualified enterprises. Therefore, it becomes the key to improve the quality management system to break the position of high qualified monopoly. In fact, the relevant departments can consider to subdivide the building markets, on the one hand, the qualification level is divided to adopt according to the 
total cost of the projects, on the other hand, the ratio between major projects and high qualification should be controlled through the administrative measures, and the low qualification's ratio should be defined to let the low qualified enterprises compete in the construction projects which is suitable to their own. It should make the high qualified consumer to return the rational consumption in this way. Secondly, the contractor should strengthen their full supervision to the affiliated side. According to the regulations with the coercive legislation, the contractor should set up the regulator of the affiliated projects and they should belong to the affiliated side' enterprise to supervise them. At the same time, the affiliated side must accept the supervision and management of the contractor. The administrative punishment should be made to them if the two parties do not perform these obligations. In addition, the relevant departments and financial institutions can also be combined to publicly supervise the two parties in order to strengthening the in-house management effect.

Correcting and changing the unreasonable ban regulations. The current laws and regulations ban to borrow the qualified business and to subcontract the construction project, but does these provisions accord with the market demand? There are a lot of the behaviors of affiliated business in the construction industry. The reason of its existence is that the construction qualification is associated with the demand to enter the market, it can lead that the qualification becomes the scarce resource. However, to obtain the construction qualification is itself required that the enterprises have to pay a lot of money and material resources, speaking from the economics. It obviously could increase their burden if the enterprises have to support a large of construction personnel and construction equipment. And the best way to solve is the professional division of labor. Because the division of labor is produced with the development of the market and it is continually subdivided and perfected according to the market demand. The division of labor degree in market is better when productivity level is higher, the resources allocation in market is more reasonable and the productivity levels are also higher when the division of labor is better. Obviously, it is a prerequisite for the professional division of labor to healthily develop the market economy. And the aim that the banning regulations were made is expected to avoid the legal risks of the affiliated business through limiting the commercial action. But the commercial action and the legal risk is not the same, because the affiliated business that are properly managed can not only avoid the legal risk to happen, but also can achieve the effect of the resources complementary. Judicially speaking, it will lead that the affiliated agreement is invalid for the banning provisions. The invalid affirmation violates the self determining principle of contract, and also creates the barrier to clear their legal responsibilities by the judicial organ. So, in the case on appeal to the contract dispute of Shanghai KunLun Construction Development Co. Ltd. 上海昆仑建设工程 发展有限公司 and the construction project by Mr. Wang, he actually think that the project cost and the mode of payment in their contract should be confirmed in respect of the parties' self determining principle in contract under the condition that the trial court believed the affiliated agreement invalid (The Civil Judgment, 2010).

Perfecting the industry's insurance system. There are the material property insurance and also the third party insurance for the target subject matter of the construction project's contract in China. The project premium is not adopted by the annual premium' ratio and adopted by the premium's ratio of work period in the matter of the insurance premium's ratio. In addition, the excluded liability of construction insurance includes that the insured and its representatives' intentional act or culpable negligence caused any losses, expenses and responsibility (An Hui, Yu Xiaoye, Zhao Guirong et al., 2012). That is to say, it is very difficult for the insured to obtain the insurance compensation when the legal risks of affiliated business have developed into the actual losses. Thus, it is not high for the insured rate of the construction enterprises in China. In fact, it is clear for this situation not to help the professional division of labor and the resource allocation in construction industry. It also can not mutually achieve the goal of fairness and efficiency even if the affiliated business was punished according to the law. And to improve the insurance system can not only provide the baseline for the affiliated business, but also utilize the market mechanism to supervise it. Therefore, it is suggested that the target subject matter of insurance should not only include the affiliated enterprise's human risk, it should also be enforced in the construction industry.

\section{Conclusion}

The basic reason that the affiliated phenomenon in construction industry is failure to prohibit repeatedly, depend on the contradiction between the management system and the current situation in market. How to let the market really play a decisive role, at the same time, to strengthen the government's regulatory capacity and to effectively maintain the market order and the rights and interests of the market subjects, a series of effective legal 
governance should be passed in order to solve these problems. Only in this way can the risks be reduced and avoided, and the development of the market economy be promoted and ensured.

\section{Acknowledgements}

This research is supported by the Multidimensional Study of Social Governance in the Southwest of China (NO.SWU1509103) and the Innovation Research of Political Philosophy and Local Government's Management (NO.2362014xk22).

\section{References}

Huang Ping 黄萍 (2009). Jianzhu Qiye Guakao de Falv Fengxian ji Fangfan 建筑企业挂靠的法律风险及防范. Xiandai Qiye, 9, 44-45.

Zhonghua Renmin Gongheguo Jianzhufa 中华人民共和国建筑法 (2005). http://www.gov.cn/ziliao/flfg/2005-08/05/content_20920.htm

Gan Xianshuang, Zhao Peng 甘贤爽, 赵鹏 (2013). Qiantan Qianli Danwei zai Gongcheng Jianshe Zhong de Anquan Falv Zeren 浅谈监理单位在工程建设中的安全法律责任. Zhongguo Gongcheng Zixun, 3, 48-50.

Lu Gang, Yan Le 卢刚, 严乐 (2012). Guanyu Jianshe Shigong zhong Zhuanbao ji Fenbao Ruogan Wenti de Tantao 关于建 设施工中转包及分包若干问题的探讨. Xi'an Jianzhu Keji Daxue Xuebao (Shehui Kexue Ban), 6, 20-25.

The Civil Judgment (2010). Shanghaishi Dier Zhongji Renmin Fayuan Minshi Panjueshu (2010) Hu 2-Civil 2-Zhong-Zi No. 842 Mingwei Neibu Chengbao Shiwei Guakao de Yize Anli-Gongcheng Guakao Zhuanti (Jiu). http://www.flzx.com/wenji/355590.html

An Hui, Yu Xiaoye, Zhao Guirong et al. 安辉, 于晓野, 赵贵荣, 等 (2012). Qiantan Gongcheng Baoxian Lipei 浅谈工程 保险理赔. Chengshi Jianshe Lilun Yanjiu (Dianzi Ban), 17. 